\title{
PERBANDINGAN KANDUNGAN PHOSPOR LAHAN GAMBIR SETELAH PENANAMAN 30 TAHUN TERHADAP LAHAN HUTAN SEKITAR
}

\author{
Synthia Ona Guserike Afner ${ }^{1}$, Andrik Marta ${ }^{2}$, Fanny Yuliana Batubara ${ }^{2}$ \\ ${ }^{1}$ Program Studi Manajemen Perkebunan, Politeknik Pertanian Negeri Payakumbuh \\ ${ }^{2}$ Program Studi Agribisnis Pertanian, Politeknik Pertanian Negeri Payakumbuh \\ J1. Raya Negara Km. 7 Tanjung Pati, 26271, Payakumbuh \\ Korespondensi: synthiaafner87@gmail.com
}

$\begin{array}{ll}\text { Diterima } & : 14 \text { Mei } 2018 \\ \text { Disetujui } & : 10 \text { Juni } 2018 \\ \text { Diterbitkan } & : \text { 15 Juli } 2018\end{array}$

\begin{abstract}
ABSTRAK
Gambir (Uncaria gambir Roxb) merupakan salah satu komoditas ekspor tradisional dari Provinsi Sumatera Barat dan Riau. Tanaman gambir termasuk dalam famili Rubiaceae. Dalam proses budidayanya, tanaman gambir masih dibudidayakan secara tradisional, dan untuk membuka lahan petani masih memakai metode pembakaran. Petani dalam melakukan budidaya gambir lebih mengandalkan kesuburan lahan tanpa melakukan pemupukan, sehingga umur produktifnya hanya 5-6 tahun, karena tanaman sudah tidak subur. Pembakaran lahan memberikan dampak yang sangat besar terhadap ekosistem, salah satunya terhadap kandungan unsur hara. Jenis analisis kimia tanah yang dilakukan meliputi : Analisis sifat kimia: (1) penetapan $\mathrm{pH} \mathrm{H} 2 \mathrm{O}$, (2) penetapan $\mathrm{P}$ tersedia,(3) Analisis sifat fisika dibatasi hanya Tekstur saja.Pembakaran dapat menghilangkan komponen air dan organik dari bahan tumbuhan (serasah, tegakan) dan meninggalkan sisa berupa bahan endapan yang disebut abu. abu dikatakan mengandung konsentrat hara yang kaya $\mathrm{Ca}, \mathrm{Mg}, \mathrm{K}$, dan $\mathrm{P}$ yang bersifat mobile. Dalam keadaan normal, unsurunsur hara dalam tumbuhan yang semula berasal dari tanah dibebaskan secara berangsur-angsur oleh proses dekomposisi biologi dan masuk kembali ke dalam tanah. Dengan metode tebang-bakar lahan yang memiliki kandungan unsur hara terbaik berada pada lahan yang baru dibuka. Hal ini disebabkan oleh variasi vegetasi yang menjadi sumbangan abu yang masuk ke dalam tanah lebih banyak dibandingkan dengan usia penggunaan lahan lain. Dari keseluruhan pengamatan, unsur $\mathrm{P}$ menunjukkan nilai tertinggi yaitu sebesar 111,54 ppm sedangkan lahan hutan disekitarnya hanya memiliki nilai $\mathrm{P}$ sebesar $4,87 \mathrm{ppm}$ dan $8,97 \mathrm{ppm}$. Hal ini membuktikan bahwa pembakaran meningkatkan kapasitas sorpsi P pada permukaan abu.
\end{abstract}

Keywords: Gambir, Tebang-bakar, Phospor

\begin{abstract}
Gambir (Uncaria gambir Roxb) is one of the traditional export commodities from the provinces of West Sumatra and Riau. Gambier plants are included in the family Rubiaceae. In the process of cultivation, gambier plants are still traditionally
\end{abstract}


cultivated, and to clear land farmers still use the burning method. Farmers in cultivating gambir rely more on land fertility without fertilizing, so their productive age is only 5-6 years, because the plants are infertile. Land combustion has a huge impact on the ecosystem, one of which is the nutrient content. Types of soil chemical analysis carried out include: Chemical properties analysis: (1) $\mathrm{pH} H 2 \mathrm{O}$ determination, (2) available P determination, (3) Physical properties analysis is limited to Texture only. Fire can eliminate water and organic components from plant material (litter, stand) and leave the remainder in the form of sediment material called ash. ash is said to contain nutrient concentrates which are rich in $\mathrm{Ca}, \mathrm{Mg}, \mathrm{K}$, and $P$ which are mobile. Under normal circumstances, nutrients in plants that originally came from the soil are released gradually by the process of biological decomposition and re-entry into the soil. With the land-cutting method that has the best nutrient content in the newly opened land. This is due to the variation of vegetation that contributes more ash to the soil compared to the age of other land uses. From the overall observation, element $P$ shows the highest value that is equal to $111.54 \mathrm{ppm}$ while the surrounding forest area only has a $P$ value of $4.87 \mathrm{ppm}$ and $8.97 \mathrm{ppm}$. This proves that combustion increases the $P$ sorption capacity on the ash surface.

\section{Keywords: Gambir, Slash-burn, Phospor}

\section{PENDAHULUAN}

Dalam proses budidayanya, tanaman gambir masih dibudidayakan secara tradisional, dan untuk membuka lahan petani masih memakai metode pembakaran. Petani dalam melakukan budidaya gambir lebih mengandalkan kesuburan lahan tanpa melakukan pemupukan, sehingga umur produktifnya hanya 5-6 tahun, karena tanaman sudah tidak subur. Selama prosesnya, pemeliharaan yang biasa dilakukan pada budidaya gambir hanya pengendalian gulma. Pengendalian gulma dilakukan dua sampai tiga kali dalam setahun sesuai dengan periode panen.

Pembakaran lahan memberikan dampak yang sangat besar terhadap ekosistem, salah satunya terhadap kandungan unsur hara. Pembakaran dapat menghilangkan komponen air dan organik dari bahan tumbuhan (serasah, tegakan) dan meninggalkan sisa berupa bahan endapan yang disebut abu. Menurut Notohadinegoro (2006), abu dikatakan konsentrat hara yang kaya $\mathrm{Ca}, \mathrm{Mg}, \mathrm{K}$, dan $\mathrm{P}$ yang bersifat mobile. Abu tidak mengandung unsur $\mathrm{N}$ karena sifat nitrogen yang mudah menguap. Dalam keadaan normal, unsur-unsur hara dalam tumbuhan yang semula berasal dari tanah dibebaskan secara berangsur-angsur oleh proses dekomposisi biologi dan masuk kembali ke dalam tanah. Daur hara alami antara vegetasi dan tanah merupakan mekanisme penting dalam kemajuan ekosistem. 


\section{I.UMIBUNG}

Di Nagari Lubuak Alai, Kecamatan Kapur IX, Kabupaten Lima Puluh Kota Tanaman gambir merupakan salah satu komoditas utama yang telah dibudidayakan petani secara turun temurun. Petani mengolah lahan dengan metode tradisional yaitu metode tebang dan bakar. Metode ini dilakukan secara terus menerus tiap proses budidaya dimulai.

\section{METODE PENELITIAN}

\subsection{Tempat dan Waktu}

Penelitian dilaksanakan di Nagari Lubuak Alai, Kecamatan Kapur IX, Kabupaten Lima Puluh Kota. Lahan yang digunakan merupakan lahan yang sudah diusahakan oleh petani untuk budidaya tanaman Gambir selama puluhan tahun. Kegiatan dilaksanakan pada bulan Februari 2017 hingga September 2017 dengan memilih kondisi lahan yang layak untuk pengambilan sampel.

\subsection{Bahan dan Alat}

Bahan dan alat yang digunakan selama penelitian ini merupakan bahan dan alat untuk survey tanah antara lain : Bor tanah, Munsehl, Abney level, Kompas dan alat-alat analisis kimia dan fisika tanah di laboratorium

\subsection{Persiapan}

Tahap persiapan dilakukan dengan pengelompokan jenis lahan berdasarkan kondisi topografi yang sama. Lahan Gambir dikelompokkan berdasarkan usia penggunaan lahannya yaitu:

1. Lahan berusia 30 tahun

2. Lahan baru dibuka

3. Lahan hutan (belum diolah)

\subsection{Pelaksanaan Penelitian}

\section{Pengambilan sampel}

Penelitian lapangan mencakup pengambilan sampel tanah pada lima jenis penggunaan lahan. Pada setiap jenis penggunaan lahan diambil sampel tanah sedalam $20 \mathrm{~cm}$ dengan bor Belgia secara komposit, pengambilan sebanyak 5 titik dengan jarak 5 m. Kelima sub-sampel diaduk merata menjadi satu sampel komposit. Jumlah sampel tanah yang dikumpulkan yaitu sebanyak 20 sampel. Sampel komposit ini kemudian 
dikeringkan, diayak dengan ayakan $2 \mathrm{~mm}$, dan selanjutnya digunakan untuk analisis kimia dan fisika tanah di laboratorium.

\section{Analisis Sampel di Laboratorium}

Sampel tanah komposit yang telah di kering anginkan, dihaluskan, dan di ayak, selanjutnya di analisis di laboratorium. Jenis analisis kimia tanah ygn dilakukan meliputi : Analisis sifat kimia: (1) penetapan $\mathrm{pH} \mathrm{H} 2 \mathrm{O}$, (1:1) dengan metode elektrometik (2) penetapan P tersedia dengan metode Bray II. Analisis sifat fisika dibatasi hanya Tekstur saja.

\section{HASIL DAN PEMBAHASAN}

\section{Kondisi wilayah Kapur IX}

Kapur IX adalah sebuah kecamatan di Kabupaten Lima Puluh Kota, Sumatera Barat, Indonesia. Kapur IX adalah salah satu dari tiga belas kecamatan yang ada di bagian timur Kabupaten Limapuluh Kota. Luas wilayah Kecamatan Kapur IX 723,36 km2 yang berarti 21,56 \% dari luas Kabuputen Limapuluh Kota yang luasnya 3.354,30 $\mathrm{Km} 2$,yang terdiri dari 7 nagari dan 31 jorong.

\section{Perbandingan Kandungan hara berdasarkan penggunaan lahan}

\section{Kemasaman tanah}

Nilai Kemasaman $(\mathrm{pH})$ terlihat bervariasi pada berbagai penggunaan lahan, nilai terendah berada pada lahan berusia 20 tahun $(4,32)$ dan tertinggi pada lahan baru dibuka (5)

Peningkatan nilai $\mathrm{pH}$ secara umum terlihat pada lahan yang telah mengalami pembakaran hingga usia 10 tahun dan menurun pada usia 20 tahun, namun keseluruhannya masih berada pada kriteria tanah masam. Adanya penurunan nilai $\mathrm{pH}$ pada usia lahan 20 tahun disebabkan oleh jenis tanah yang memang memiliki kisaran pH masam hingga agak masam. Menurut Damanik et al. (2011) reaksi tanah Inseptisol ada yang masam sampai agak masam $(\mathrm{pH} 4,6$ - 5,5) dan agak masam sampai netral ( $\mathrm{pH}$ $5,6-6,8)$. Dengan $\mathrm{pH}$ tanah yang demikian sudah cukup bagi tanaman gambir untuk dapat tumbuh dan berproduksi. Perubahan nilai $\mathrm{pH}$ ini sangat bergantung kepada jumlah kation terlarut di dalam tanah. Khanna et al (1994) melaporkan bahwa penambahan kation larut dalam abu dalam $\mathrm{pH}$ tanah merupakan faktor utama yang mempengaruhi 
pelarutan dan reaksi pertukaran di tanah. awalnya kelarutan abu terutama merupakan fungsi dari kandungan kation larut seperti $\mathrm{K}, \mathrm{Na}$, dan $\mathrm{NH} 4$ yang memasuki fase larutan. Widyasari (2008) dalam penelitiannya menunjukkan nilai rata-rata $\mathrm{pH}$ mengalami peningkatan sebesar 0,37 yaitu 3,08 pada tanah tidak terbakar menjadi 3,45 pada tanah bekas terbakar 2 tahun

\section{P-tersedia tanah}

Dari keseluruhan unsur yang dianalisa, nilai P-tersedia memperlihatkan nilai yang sangat variatif dari keseluruhan penggunaan lahan yaitu berada pada criteria sangat rendah hingga tinggi. Dari keseluruhan pengamatan, unsur P menunjukkan nilai tertinggi yaitu sebesar 111,54 ppm sedangkan lahan hutan disekitarnya hanya memiliki nilai P sebesar 4,87 ppm dan 8,97 ppm.. Romanya et al (1994) dalam penelitiannya melaporkan $\mathrm{P}$ organic dan total meningkat setelah tebang dan bakar, kenaikan ini terbukti di permukaan tanah dan sangat bergantung pada intensitas pembakaran. Pembakaran meningkatkan kapasitas sorpsi P pada permukaan abu.

\section{KESIMPULAN}

Dari penelitian Perbandingan kandungan hara berdasarkan usia penggunaan lahan gambir yang telah dilakukan di Kecamatan kapur IX didapatkan bahwa pengolahan lahan dengan metode tebang dan bakar memberikan pengaruh terhadap kandungan unsure hara dalam tanah. Bila lahan hutan dijadikan sebagai control, maka terlihat beberapa unsur hara meningkat setelah dilakukan proses pembakaran. Peningkatan kandungan unsur hara ini disebabkan oleh sumbangan abu yang dihasilkan sebagai hasil sisa dari pembakaran lahan. Pada keseluruhan lahan yang diamati sebagai sampel, lahan baru dibuka menunjukkan nilai perubahan yang cukup jelas bila dibandingkan dengan lahan hutan. Secara kriteria pada lahan yang baru dibuka, kandungan keseluruhan unsur hara mengalami peningkatan, bahkan nilai P berada pada kriteria tinggi yaitu sebesar 111,54 ppm hal ini sangat kontras dibandingkan dengan lahan hutan yang hanya mengandung $\mathrm{P}$ sebesar 8,97 ppm saja. 


\section{REFERENSI}

Notohadinegoro, Tejoyuwono. 2006. Konsep Sempit Lingkup Pertanian, Kendala Berat Bagi Pembangunan Nasional. Ilmu Tanah Universitas Gadjah Mada. Yogyakarta.

Damanik, M.M.B., E.H. Bachtiar., Fauzi., Sarifuddin dan H. Hamidah. 2011. Kesuburan Tanah dan Pemupukan. USU Press, Medan

Khanna, P.K., Raison, R.J., Falkiner, R.A., 1994. Chemical properties of ash derived from Eucalyptus litter and its effects on forest soils. For. Ecol. Manage. 66, 107125

Widyasari, N. dan A. Eka. 2008. Pengaruh Sifat Fisik dan Kimia Tanah Gambut Dua Tahun setelah Terbakar Dalam Mempengaruhi Pertumbuhan Accacia crassicarpas. Cunn. Ex Benth di Areal IUPHHK-HT PT. Sebangun Bumi Andalas Wood Industries. Skripsi. Institut Pertanian Bogor 